\title{
Functional equilibrium: sense or nonsense?
}

\section{R. Brouwer}

Department of General Botany, State University of Utrecht, Lange Nieuwstraat 106, 3512 PN Utrecht, Netherlands

Key-words: root growth, shoot growth, shoot/root ratio, functional equilibrium, root-zone temperature, light intensity, nitrogen nutrition, defoliation, root pruning

\section{Summary}

The distribution of dry matter over shoots and roots of vegetative plants in dependence on various environmental conditions and experimental interventions is discussed.

Since it is rather difficult to maintain conditions at a sufficiently constant level for some time, functional equilibria are not likely to exist during prolonged periods of time.

From the responses occurring after transferring plants from one condition to another or after disturbance of existing relationships, it is demonstrated once more that nutritional control, i.e. functional control, of the distribution is still the most reasonable interpretation of the observed reaction patterns.

\section{Introduction}

The differences between roots and shoots, regarding their morphological, anatomical and physiological features, are so large that they can be considered as two systems within the intact plant. Their functions are complementary, since the shoot collects resources as a basis for energy supply and organic compounds whereas the roots absorb mineral nutrients, nitrogen and water. Both have to meet the supply of the whole plant; this makes the two organs dependent upon each other. In the intact plant their functions are combined to an integrated system. We are as yet far from a complete understanding of the functioning of this system. What we do know is that shoots and roots are growing in strict harmony with one another and that the ratio between them is highly predictable under a great variety of external conditions.

The relation between shoot and root growth can be demonstrated by plotting shoot weight against root weight, both obtained by successive harvests during the life cycle. In annuals with a determinate development various phases can be distinguished, each of which is recognizable by its own distinct distribution pattern. During the germination stage before emergence root growth is favoured; instantaneously after emergence shoot weight increases relatively fast, whereas during the subsequent vegetative growth another, but constant, distribution is maintained for some time. After flowering shoot growth dominates, particularly fruit growth; root weight may even decrease during this phase. 


\section{R. BROUWER}

Research on the underlying mechanisms has concentrated on either the vegetative stage (Troughton, 1977) or on the generative phase (Michael, 1980). The present paper deals with regulation of the distribution patterns during vegetative development. The results obtained so far have shown that the distribution pattern depends on the species or ecotype; within each species on the stage of development, and within a particular stage on external conditions. Since the distribution patterns reflect growth rates of the various parts, it is evident that these growth rates are under mutual control. There has been and still is considerable disagreement on the underlying physiological mechanisms (Troughton, 1977; Wareing, 1979; Lambers, 1979). This discussion centers around the following observations.

a) When growth is limited by an essential substance to be absorbed by the roots, root growth is relatively favoured; when the limiting factor has to be absorbed by the shoot, growth of above-ground parts is relatively favoured.

b) Disturbance of the shoot/root ratio that exists in any condition, either by root cutting or by defoliation, leads to such changes in the growth pattern that the original ratio is restored rapidly.

c) Transfer of plants from one condition to another gives rise to changes in the distribution pattern so that the ratio characteristic of the new situation is reached in due time.

The interpretation of these responses can be kept rather simple by assuming that during undisturbed development roots and shoots are competing for carbohydrates and minerals, and that the organ that will be most successful in obtaining its requirements is the one that is nearest to the source. Reduction of overall carbohydrate supply (lower light intensity, defoliation) accentuates the competition, which is more harmful to root growth than to shoot growth. Reduction of root-bound supply (nitrogen withholding, water shortage, root pruning) intensifies the competition too, and strikes shoot growth more than root growth. Such reasoning is based on the mutual influence of the various organs via nutrient supply. However, it is well known that the shoot and the root are supplying each other with growth regulators (hormones) as well. A discussion of the feedback mechanisms of the mutual control should consider the possible mediation by both nutrients and hormones. However, hormonal aspects are not treated at large in the present paper.

\section{Experimental approach}

The most relevant answers to the questions raised above may be expected from experiments in which the time course of as many processes as possible has been analysed before and after a change in growing conditions or surgery. Unfortunately the majority of experiments reported in literature is dealing with only a few aspects. Hence one has to build up the evidence by fitting the pieces together. In the present chapter a number of experiments will be presented which are considered to be relevant to the problem.

\section{A few aspects of plant performance}

Plants respond to external conditions by variation in both size and number of build- 
ing elements. During development the number of established elements (leaves, root axes) steadily increases. The duration of growth of each element is limited. Whereas some elements grow out, other elements remain in a meristematic state (axillary buds, part of the root primordia). Since these meristematic elements are potentially able to grow, their presence makes a higher plant very flexible in its responses to improving conditions or to disturbance. In many cases growth rate is strongly correlated with the outgrowth of new elements. Sometimes a growth re sponse cannot be obtained to the maximum extent before a sufficient number of new leaves or axes is initiated.

Another rather striking phenomenon is that, being part of a whole, no single element reaches the size it could obtain without interference from similar elements of the same individual (Loomis, 1953; Brouwer \& Locher, 1965).

\section{Defoliation and root pruning}

The interpretation of the overall course of these responses is rather simple. Complete or partial leaf excision leads to a drastic reduction of carbohydrate synthesis. Thanks to the ample availability of water and minerals, existing leaf primordia are able to grow vigorously, consuming the concomitant production of carbohydrates and part of the reserves (Alberda, 1966). In the meanwhile root growth is checked completely (Alberda, 1966; Ennik, 1976; Davidson \& Milthorpe, 1966). One or two days after clipping carbohydrate levels in the root become critical, with a concurrent reduction of mineral absorption and respiration (Davidson \& Milthorpe, 1966). Afterwards the increasing green area takes care of a gradual recovery of the original situation (Ennik, 1976). This behaviour supports - or at least it is not incompatible with - the hypothesis of a regulation of the growth rate of shoots and roots via a combined competition for the shoot-born carbohydrates and the rootborn mineral supply (functional control).

When part of the roots is cut off, water and mineral absorption is hampered. Since the transpiration is determined mainly by leaf area and stomatal width, partial root pruning does not readily affect the amount of water transported through the plant, but the waterpotential gradient will increase. Generally this will lead to a reduced leaf extension rate and - as a consequence of the reduced use of carbohydrates - to an increase in the concentration of reserve carbohydrates. In this way the increased relative growth rate of the roots left on the plants can be explained. When nitrate absorption becomes the limiting factor, mutatis mutandis, a similar reasoning can be followed.

Again the overall response fits rather well in the hypothesis of a functional balance.

Cutting down the number of crown roots of developing grass plants gave comparable results (Brouwer \& Kleinendorst, 1965). In Fig. 1 a comparison is made between the growth of tillers limited to the first two crown roots (R) and tillers growing undisturbed (A). At first shoot growth of the '2-root' plants was a little faster, presumably due to a reduced competition comparable with similar effects reported by Kny (1894) during the germination of wheat. During subsequent growth (Fig. 1) the undisturbed plants got far ahead of the treated plants, notwithstanding the com- 

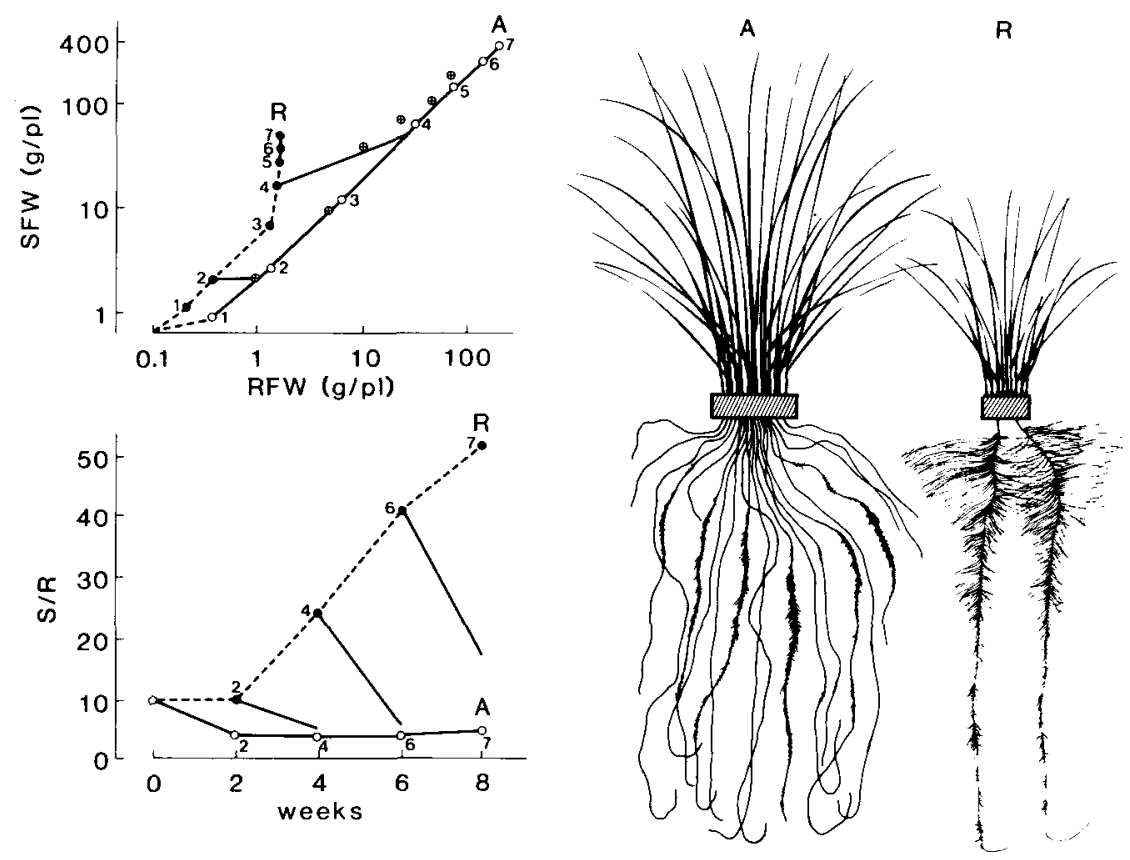

Fig. 1. Top: relation between root fresh weight and shoot fresh weight of perennial ryegrass plants developing from a single tiller. A. Plants undisturbed, all roots left on the plant. R. Number of roots reduced by cutting all developing roots before they had reached a length of $1 \mathrm{~cm}$, with the exception of the two first-appearing roots. Root excision was stopped at harvest time 2,4 or 6 in different treatments. Numbers in the graphs indicate successive weekly harvests. Bottom: changes in the shoot/root ratios at the treatments.

pensatory growth in the system with two roots only. After some time the latter root system stopped growing completely. The shoot weight still increased, as wel as the number of tillers (Brouwer \& Kleinendorst, 1965), although at a low rate. After termination of the cutting treatment a very rapid root growth reduced the abnormally high shoot/root ratio to a normal level in 7-10 days, consuming the reserve carbohydrates which had been accumulated during the treatment.

These treatments show clearly that enforced limitations of root growth give rise to a gradually increasing reduction in shoot growth. During the treatment reserve carbohydrates accumulate, which are used in root growth after alleviation of the limitation. The accumulation of reserve carbohydrates in the leaves may reach very high levels of up to $50-70 \%$ of the dry matter. The results also indicate that the larger the content of reserves the faster the root growth.

\section{Changes in external conditions}

Nitrogen nutrition. The level of the nitrogen nutrition has been found to influence strongly the ratio between shoot growth rate and root growth rate. In most cases re- 
ferred to in literature the responses are effects of amounts of nitrate or ammonium supplied rather than of concentrations. Even at very low concentrations the absorption rate is rather high, especially in nutrient solution (Freysen, 1983; Novoa \& Loomis, 1981). Only when sufficient precautions are taken to keep the quantities in pace with plant development (Ingestadt, 1974, 1977, 1979 a, b, c; Corré, 1983) exponential growth can be maintained for some time. In such cases transitions from one ratio to another can be obtained easily.

At low daily doses of $\mathrm{NO}_{3}{ }^{-}$dry matter percentage and soluble sugar or starch concentrations (as a percentage of dry weight) tend to be higher than at higher daily doses (Alberda, 1965; Deinum, 1966). These responses fit very well in the concept that competition for carbohydrates and nitrogenous compounds are regulating the ratio between growth rates of shoots and roots. Transferring plants from a solution without nitrate to a nitrate-containing nutrient solution leads to a rapid change from a large share of the root in the total plant weight to a high shoot/root ratio. The response is achieved by a very fast shoot growth (Spek, 1983) of short duration and a concomitantly retarded root growth. The relatively large root system at the transition, supported by the high concentration of reserve carbohydrates (Louwerse, 1967), results in a rapid increase in nitrate and organic-N content (Spek, 1983) in the shoots, which favours leaf appearance, leaf elongation and photosynthesis to a level well above that in the plus nitrate control plants (overshooting).

Varying the nitrogen supply from a high level to zero results in a non-equilibrium situation. The distribution pattern does not change much as long as free nitrate is available in the tissue. However, when the internal nitrate content approaches zero, the redistribution of organic-N compounds is going to determine growth (Spek, 1983). In that condition root growth gradually takes the lead over shoot growth, as expected on the basis of the considerations put forward in a former section. In the meanwhile dry matter content and soluble sugar content are increasing (Brouwer et al., 1963; Spek, 1980, 1983). Ultimately, when all the nitrogen compounds are redistributed, growth activity of the meristems becomes very low. During prolonged $\mathrm{N}$ starvation not only growth rate but also responsiveness to renewed supply of nitrogen nutrition decreases (Brouwer, 1967), indicating that the state of the meristems in the growing point is important for the reaction of plants to changing conditions. This might be the reason why plants from infertile habitats are less responsive to high fertilisation levels (Chapin, 1980). In our experiments the response to improved nitrogen nutrition in Plantago lanceolata, which readily gerrerates new leaves and axillary sprouts, was approximately the same as in maize, and much faster than the response of the slowly developing Carex flacca (Fig. 2). In maize, well supplied with nitrate, cooling of the shoot meristem strongly reduced leaf growth and leaf appearance and shifted the dry matter distribution in favour of root growth.

It is clear this general picture that data as obtained by Deinum (1966), in experiments with a combination of light levels and nitrogen nutrition levels are at least qualitatively understood, as far as the $\mathrm{C}-\mathrm{N}$ relation of the plant is concerned.

To come from this general scheme to the actual distribution of dry matter over the various plant parts, the central role of transpiring, photosynthesizing, importing 

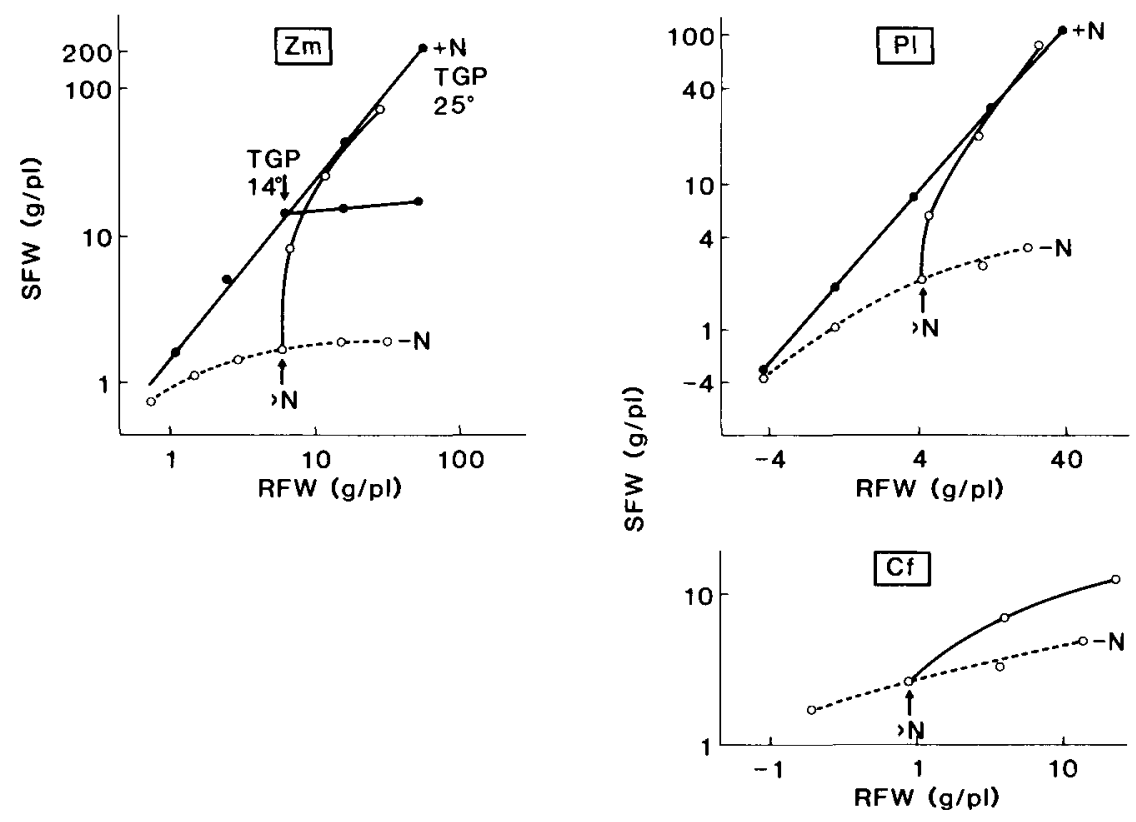

Fig. 2. Relation between root fresh weight and shoot fresh weight in Zea mays $(\mathrm{Zm})$, Plantago lanceolata $(\mathrm{Pl})$ and Carex flacca $(\mathrm{Cf})$ during development (increasing weight indicates subsequent harvests). Treatments: - — continuously well supplied with nitrate; 0 - - $\odot$ nutrient solution without nitrate; $0-0$ transferred from low to high nitrate concentration, at the stages indicated by 'arrow' $>\mathbf{N}$. For part of the maize plants well supplied with nitrate the growing point of shoots was cooled to $14{ }^{\circ} \mathrm{C}$ from the stage indicated by TGP (temperature growing point) $14^{\circ}$ 'arrow' onwards.

and exporting full-grown leaves has to be emphasized.

Such a leaf imports nitrate and amino acids via the xylem tracks. The nitrate transported to the leaf in the transpiration stream is accumulated in a vacuolar pool. In a steady state condition the $\mathrm{NO}_{3}{ }^{-}$pool will have a more or less constant concentration since the reduction to amino acids will equal the amount that is imported. The amino acids produced are mixing in a pool with amino acids resulting from the turn-over of proteins. In a steady state the net gain in amino acids will be exported in the phloem to the sink regions in both the shoot and the root. How much flows to each of them depends on the local rate of unloading (growth conditions at the sinks) and distance (resistance).

Some sinks, such as growing regions that are not transpiring, depend completely on the more or less ideal composition of the phloem sap for their initial supply. Other sinks, such as the roots, have the opportunity to absorb additional nutrients $\left(\mathrm{NO}_{3}{ }^{-}\right)$from their environment.

Based on the high protein content of leaf tissue it may be assumed that at favourable $\mathrm{N}$ supply the phloem sap is very suitable for leaf growth, and due to priority (distance and structure of the pathway) a great part of it flows to leaf primordia. If the phloem sap continues to be of good quality and high quantity, the meristematic 
regions of the leaves may enlarge and relative growth rates of the meristematic regions remaining high, absolute growth rates are increasing (Kemp, 1981). The phloem sap, having a suitable $\mathrm{C}-\mathrm{N}$ ratio for leaf growth, will not be unsuitable for root growth, but under these conditions roots will get very little of the sap, due to the priority of the leaf primordia mentioned before.

As to the level of nitrogenous compounds in the various compartments, literature indicates a lower $\mathrm{NO}_{3}{ }^{-}$concentration at higher light intensities. The organic- $\mathrm{N}$ content is less dependent on the light intensity, at least when considered on the basis of structural dry weight. The concentrations in the roots are only about one half to two-thirds of those in the shoots. Differences may occur between species and within a species between stages of development.

Reduction of the nitrate supply to the roots leads to a rapid exhaustion of the internal $\mathrm{NO}_{3}{ }^{-}$concentration in roots and leaves. This means that the net gain in amino acids gradually decreases in both roots and shoots. The loading of the phloem with amino acids decreases and the $\mathrm{C} / \mathrm{N}$ ratio increases. In the extreme case when the nitrate supply to the leaves is checked completely, phloem loading with amino acids depends on the amino acids released from the protein turn-over. In fact, a kind of competition for amino acids may be assumed between the phloem loading process and the rebuilding of protein. The reduced cytokinin supply to the transpiring leaves as a consequence of reduced cytokinin production in nitrogen-starving roots (Wagner \& Michael, 1971) diminishes the rebuilding capacity (protein synthesis) and leads to exhaustion of nitrogenous compounds in the leaves (senescence). $\mathrm{Ku}$ layeva (1969) showed that lack of cytokinin is involved since local application resulted in green spots on leaves of $\mathrm{N}$ starved maize plants, but according to Leopold (1961) auxin might be involved in this self-destruction ('Erschopfungstod') as well. It is quite logical that at the end of the starvation process proteins are still involved in the phloem loading and transport. The transport will slow down, but as long as there is still transport activity the transported material will contain some $\mathrm{N}$ compounds besides the carbohydrates.

\section{Changes that reduce root growth}

At root temperatures of $10^{\circ} \mathrm{C}$ and of $35^{\circ} \mathrm{C}$ root growth of bean plants ceased almost completely (Fig. 3). Dependent on the effect of temperature on root function (Brouwer \& Hoogland, 1964) shoot growth rate is initially increased (at $35^{\circ} \mathrm{C}$ ) or decreased (at $10^{\circ} \mathrm{C}$ ), but rather soon shoot growth stops as the non-growing roots stop functioning. Ultimately the leaves are senescing and the plants die.

Cooling the roots of maize plants from $20^{\circ} \mathrm{C}$ to $10^{\circ} \mathrm{C}$ or $15^{\circ} \mathrm{C}$ results in an immediate reduction of leaf extension (Grobbelaar, 1963). During the first and second day following the beginning of the treatment dry matter content and concentration of soluble carbohydrates in the shoots rise rapidly, coinciding with a strong reduction of the investment of dry matter in the roots. Repeating this experiment a number of times revealed that after one day of treatment the total dry weight of the shoots was higher in the treated plants than in the control plants. Heating of the root system tot $40{ }^{\circ} \mathrm{C}$, which also stopped root growth, was even more effective and for a longer time ( 3 days). 


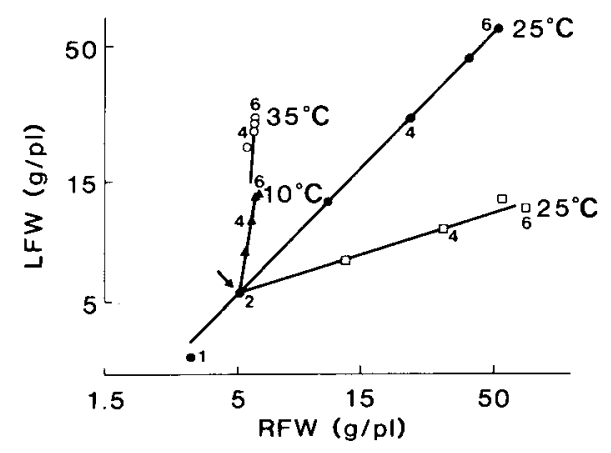

Fig. 3. The relation between root fresh weight and leaf fresh weight of developing bean plants grown on Hoagland nutrient solution. Air temperature $20-24^{\circ} \mathrm{C}$. Light intensity $80 \mathrm{~W} \mathrm{~m}^{-2}$, during $16 \mathrm{~h}$ per day. Plants were harvested twice a week. Numbers indicate successive harvests. Treatments: Black dots: root zone temperature $25^{\circ} \mathrm{C}$ throughout; Circles: root zone temperature changed to $35^{\circ} \mathrm{C}$ at harvest 2 (arrow); Triangles: root zone temperature changed tot $10^{\circ} \mathrm{C}$ at harvest 2 (arrow); Squares: root zone temperature $25^{\circ} \mathrm{C}$ throughout; shoot growing-points appearing after unfolding of the primary leaves constantly removed.

Waterlogging of the soil is known to stop root growth of many plants. Shoot growth responds to waterlogging in almost the same way as to root-cooling by a reduced extension growth and an accumulation of dry matter (Brouwer, 1977; Trought \& Drew, 1980). Although total dry matter production during prolonged treatment follows leaf area rather closely, during the first and second day the dry weight of the shoots of the treated plants tends to be higher than that of the control plants, indicating again that in the well-aerated situation shoots and roots are competing for carbohydrates.

\section{Changes that reduced leaf growth}

Reducing growth capacity of the shoot by excision of growing points leads to a shift in the shoot/root ratio by continuing root growth (Fig. 3, squares). This response can go on for a prolonged time leading to enormous root systems on a relatively small shoot mass (cf. Humphries, 1958).

Cooling the growing region of the leaves reduces leaf elongation in maize instantaneously (Brouwer et al., 1973; Kleinendorst \& Brouwer, 1970). At the same time carbohydrates are accumulating, whereas root growth relative to shoot growth is promoted. The low temperature of the leaf bases (cooling of the growing point of maize includes cooling of the leaf sheaths surrounding it) might affect translocation. However, initially the overall transport of dry matter to the roots exceeds that of the controls. This means that root growth profits from carbohydrates not being used in shoot growth, indicating that at the very moment of the start of the treatment root growth and shoot growth were competing for carbohydrates (Fig. 2).

\section{Split-root systems}

Thanks to the presence of a great number of growing points root systems are very 


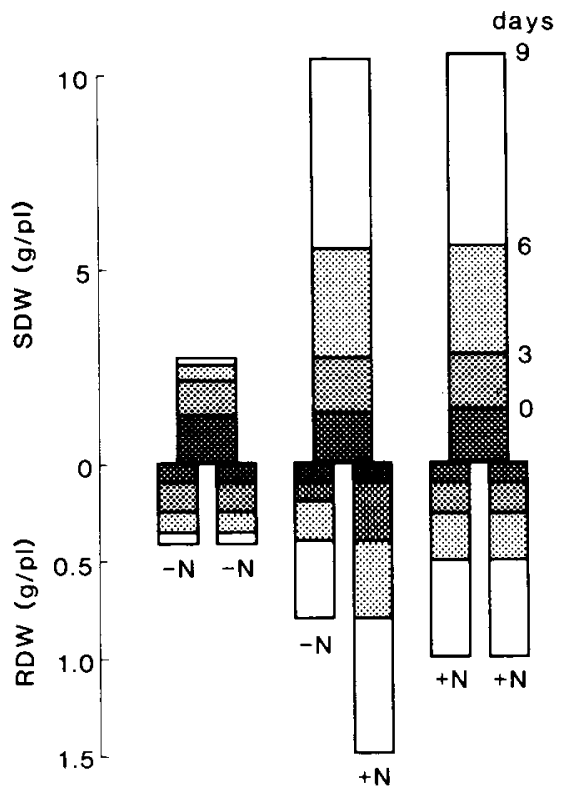

Fig. 4. Shoot and root growth of maize plants pre-grown on Hoagland solution. During the pre-treatment all roots except 4 crown roots of the first whorl were removed. At the beginning of the experiment the plants were transferred to a split-root set-up; each of two vessels contained 2 roots and either a complete Hoagland nutrient solution $(+N)$ or a Hoagland solution in which $\mathrm{N}$ was replaced by $\mathrm{Cl}^{-}(-\mathrm{N})$. Harvests were made at zero time and subsequently 3,6 and 9 days later.

flexible in their response to the local environment. It has been shown that local variations in soil water content result in root growth at places where the combination of oxygen and water availability is optimal (El Nadi et al., 1969; Scott Russell, 1977).

By varying the relative gas exchange rate for two 'halves' of a crown root system of maize the ratio of the growth rates can be changed at will (Brouwer, 1981). The data show that one half of the root system is able to sustain normal shoot growth by compensatory growth. Even better known are the effects of local concentrations on root growth in the most fertile regions of the soil (Gliemeroth, 1955; Drew, 1975). These observations show that various parts of the root system are attracting carbohydrates from the shoots in accordance with the favourability of their environment. This type of response and the readiness by which it occurs, make a set-up with splitroot systems very suitable for the study of shoot-root relationships. Good examples are the early experiments of Gile \& Carrero (1917) and of Goedewaagen (1955). The latter showed that phosphorus applied at a limiting level to one half of the root environment of oat plants stimulated root growth in that part considerably, at the expense of root growth in the unfertilized half of the container. Since under these conditions above-ground development and total root growth were the same, these experiments indicate that, notwithstanding the differences in distribution, the relative investment of dry matter in the root system was not affected. At higher P dressings the differences in root development between the fertilized and the unfertilized 


\section{R. BROUWER}

compartment gradually disappeared. It is tempting to assume that because of the higher phosphorus content of the above-ground parts, the phloem sap provides sufficient phosphorus to meet the requirement of the roots in the unfertilized compartment, so that these roots could compete with the roots that had an additional supply from the medium.

These results were confirmed in experiments in water culture by Brouwer \& Loen (1962), using local applications of nitrate. De Jager $(1979 ; 1982)$ and De Jager \& Posno (1980) extended this work, using local applications of all macronutrients $\left(\mathrm{K}, \mathrm{Mg}, \mathrm{Ca}, \mathrm{SO}_{4}, \mathrm{H}_{2} \mathrm{PO}_{4}\right.$ or $\left.\mathrm{NO}_{3}\right)$. They supplied one-fourth of the roots of maize plants with one of these nutrients whereas the other $3 / 4$ part did not receive this particular nutrient. This resulted in a local increase of both growth rate and absorption rate (cf. Goedewaagen, 1955; Gile \& Carrero, 1917) so that shoot growth rate was comparable with that of the fully supplied plant. During the first days the enhanced growth of the supplied part of the root system took place at the cost of the growth of the root part that was not supplied with one of the nutrient elements. After some days, however, the roots that had no external supply started to grow faster because of the internal supply of the nutrient by the phloem stream. This explanation is the more evident since this recovery of the growth of the non-supplied roots did not occur when calcium was locally applied.

All these results are in agreement with the assumption that in plants with a fast growing shoot a limited amount of carbohydrates is available for root growth. The partitioning within the root systems seems to be governed by the favourability of local conditions and can be changed at will (Brouwer, 1981).

After reaching the equilibrium situation in all these cases the ratio shoot weight over total root weight fits in a very narrow range, indicating that now some other factor is determining the distribution over both organs. This factor might be water.

\section{The relevance of the water balance}

For the water status of a plant it is very important that consumption (transpiration and water tied up in the tissues) and supply are tuned in to each other. Yet there are continuous disturbances of the water balance. With optimal water supply during the daily light period transpiration increases and decreases in proportion to evaporation. Concomitantly plant water potential accompanied by changes in turgor potential decreases and increases. Since leaf extension depends directly on the turgor of the elongating cells, daily patterns of leaf elongation rates are to be found that follow evaporative conditions rather closely.

These patterns, observed in a greenhouse in plants grown in water culture, are accentuated in soil culture even with optimal water supply, and they are intensified when the water supply is reduced. As there are differences between species in the extent of osmotic adjustment (Jones \& Turner, 1978; Bradford \& Hsiao, 1982), there will be a quantitatieve difference in response depending on the species used.

However we may conclude that at optimalization of the nutrient supply the water supply ultimately determines the amount of roots per gram shoot necessary to maintain maximum growth rate (Huck et al., 1983; van Noordwijk, 1983). 


\section{Concluding remarks}

\section{Validity of the interpretations}

The phenomena as described above are common knowledge, but the question may be raised and has been raised (Wareing, 1979; Lambers, 1979), whether we really understand what is going on in physiological terms. The answer will be 'no', 'insufficiently' or 'almost', depending on the character, the discipline, and the interest of the investigator. A number of important peculiarities of higher plants can be credited for the existing divergence of opinion.

In the first place there is the discrepancy between growth in dry matter (on which most of the distribution diagrams are based) and growth in exposed area (which is most likely the determining item with regard to the functioning of plant parts, at least when the exchange with the environment is considered) (Brouwer et al. 1973).

In the second place it is often very difficult to distinguish between structural material and non-structural 'reserves'. 'Reserves' of carbohydrates, measured as soluble carbohydrates, may yet be functional in an osmotic way. Similarly, the presence of starch in a root tip may have a function in its geotropic reaction. On the other hand it is quite clear that many constraints of growth lead to an accumulation of carbon compounds (van Dobben, 1961; Grobbelaar, 1963; Brouwen \& Hoogland, 1962; Brouwer et al., 1963). A comparable question arises concerning the nitrogenous compounds. Besides the uncertainty whether amino acids and soluble proteins are structural units or reserves, a large variation in internal nitrate concentration will be easily considered to be a variation in $\mathrm{N}$ reserves, but it might still be functional in cell enlargement (van de Dijk, 1982) or only so at low light intensities (Alberda, 1965; Deinum, 1966). It has been demonstrated sufficiently that nitrate accumulates in cells in cases where a poor energy supply acts as a constraint of growth (low light intensity, high temperatures).

A third characteristic of importance for the time course of the reaction upon changing conditions or upon disturbance of an existing distribution is the readiness of the plants to respond. After a heavy cut regrowth is rather slow as a consequence of reduction in number and/or quality of axillary buds. Heavy nitrogen starvation in maize postpones the response to a more favourable nitrogen supply (Brouwer, 1967). Species from naturally infertile habitats may even lack the usual responsiveness to fertilization (Chapin, 1980).

The complications above mentioned (and there are certainly many more) (Throughton, 1977) may cause apparent contradictions with regard to the evidence of a regulatory mechanism based on nutritional factors. Some of these contradictions can be explained by theories based on the actions of hormones, but as yet the available knowlegde on hormone balances is of more use qualitatively than quantitatively.

\section{Use of simulation models}

How far we have progressed with our understanding of growth responses can be demonstrated by incorporating existing knowledge in simulation models.

A number of them are mimicking plant behaviour rather well (Reynolds \& 


\section{R. BROUWER}

Thornley, 1982; de Wit et al., 1970; Seligman et al., 1975; Sinclair \& de Wit, 1975; 1976). All these models have in common that they are using many causal relationships. However, a number of aspects are still suppositions based on empirical data only. These aspects have a bearing on the morphology of the plants (Brouwer \& de Wit, 1969), and the transport system within the plant (de Wit et al., 1970; Seligman et al., 1975; Thornley, 1977). Obviously there are gaps in our knowledge regarding these aspects.

The introduction of empirical data is often necessary to keep the model plant in pace with the results of experiments. It is particularly difficult to reach and maintain equilibrium situations, e.g. with regard to $\mathrm{C} / \mathrm{N}$ ratios. Then these ratios have to be prescribed to the model (Reynolds \& Thornley, 1982). Obviously assumed feedback mechanisms fail to work adequately. This raises the question whether equilibrium situations are so common as indicated by experiments as shown in the former sections. Throughton (1977) stated that 'if there is a mechanism leading to the maintenance of a fixed $\mathrm{C} / \mathrm{N}$ ratio it is not perfect'. In many cases such imperfect regulations have been ascribed to ontogenetic drift (Troughton, 1977) but it might just be that seemingly imperfect regulations can teach us a lot more of the physiology of plant performance than equilibrium situations if there are any.

Non-equilibrium situations are normal in both the field situation and most laboratory experiments.

\section{Acknowledgements}

The present paper would not have been written without the efforts made by technicians and students who helped me with the experiments, and without discussions with colleagues from various institutes all over the country and abroad. I owe them all very much and at the end of my career I realize that they have meant even more for my personal life.

I would like to thank them all by mentioning the names of the organizers of this symposium: Prof. Dr O. M. van Andel, Miss E. A. L. van Rhijn, Drs L. Y. Spek, Drs A. Stienstra, Dr R. Soekarjo and Drs H. J. P. A. Verkaar, who have spent so much time to make my official retirement a pleasant occasion.

\section{References}

Alberda, Th., 1965. The influence of temperature, light intensity and nitrate concentration on dry matter production and chemical composition of Lolium perenne L. Neth. J. agric. Sci. 13:335-360.

Alberda, Th., 1966. The influence of reserve substances on dry matter production after defoliation. Proc. 10th int. Grassl. Congr., pp. 140-147.

Bradford, K. J. \& T. C. Hsiao, 1982. Physiological responses to moderate water stress. In: O. L. Lange et al. (Ed.), Encyclopedia of Plant Physiology New Series Vol. 12B.

Brouwer, R., 1967. Beziehungen zwischen Spross- und Wurzelwachstum. Angew. Bot. 41: 244-254.

Brouwer, R., 1977. Root functioning. In: J. J. Landsberg \& C. V. Cutting (Eds), Environmental effects on crop physiology. Academic Press, pp. 229-245.

Brouwer, R., 1981. Co-ordination of growth phenomena within a root system of intact maize plants. Plant and Soil 63: 65-72. 
Brouwer, R. \& A. Hoogland, 1964. Responses of bean plants to root temperatures. II. Anatomical aspects. Jaarb. Inst. biol. scheik. Onderz. Landbouwgewass. 1964: 23-31.

Brouwer, R., P. J. Jenneskens \& G. J. Borggreve, 1963. Growth responses of shoots and roots to interruptions of the nitrogen supply. Jaarb. Inst. biol. scheik. Onderz. Landbouwgewass. 1961: 29-36.

Brouwer, R. \& A. Kleinendorst, 1965. Effect of root excision on growth phenomena in perennial ryegrass. Jaarb. Inst. biol. scheik. Onderz. Landbouwgewass. 1965: 11-20.

Brouwer, R., A. Kleinendorst \& J. Th. Locher, 1973. Growth responses of maize to temperature. In Unesco Proc. Uppsala Symp., pp. 169-174.

Brouwer, R. \& J. Th. Locher, 1965. The significance of seminal roots in growth of maize. Jaarb. Inst. biol. scheik. Onderz. Landbouwgewass. 1965: 21-28.

Brouwer, R. \& E. A. Loen, 1962. Growth and uptake of individual crown roots of maize. Jaarb. Inst. biol. scheik. Onderz. Landbouwgewass. 1962: 19-25.

Brouwer, R. \& C. T. de Wit, 1969. A simulation model of plant growth with special attention to root growth and its consequences. In: W. J. Whittington (Ed.), Root growth. Butterworths, London, pp. $224-244$

Chapin, F. S. III, 1980. The mineral nutrition of wild plants. Ann. Rev. Ecol. Syst. 11: 233-260.

Corré, W. J., 1983. Growth and morphogenesis of sun and shade plants. III. Interactions between light intensity and nutrient supply. Acta Bot. neerl. (in press).

Davidson, J. L. \& F. L. Milthorpe, 1966. Leaf growth of Dactylis glomerata following defoliation. Ann. Bot. (N.S.) 30: 173-184.

Deinum, B., 1966. Climate, nitrogen and grass. I. Research into the influence of light intensity, temperature, water supply and nitrogen on the production and chemical competition of grass. Meded. Landbouwhogesch. Wageningen 66-11: 1-91.

Dobben, W. H. van, 1961. Nitrogen uptake of spring wheat and poppies in relation to growth and development. Jaarb. Inst. biol. scheik. Onderz. Landbouwgewass. 1961: 45-60.

Drew, M. C., 1975. Comparison of the effects of a localized supply of phosphate, nitrate, ammonium and potassium on the growth of the seminal root system and the shoot in barley. New Phytol. 75: 479 . 490.

Dijk, S. van de, 1981. Nitrogen metabolism in higher plants in different environments. Thesis, Groningen.

El Nadi, A. H., R. Brouwer \& J. Th. Locher, 1969. Some responses of the root and the shoot of Vicia faba plants to water stress. Neth. J. agric. Sci. 17: 133-142.

Ennik, G. C., 1976. De invloed van stikstofbemesting en oogstfrequentie op de beworteling van gras. De Buffer 22: 1-5.

Freysen, A. H. J., 1983. De opnamesnelheid van nitraat bij hogere planten: ecologische aspecten. Vakbl. v. Biologen 63 (1): 9-11.

Gile, P. L. \& J. O. Carrero, 1917. Absorption of nutrients as effected by the number of roots supplied with the nutrient. J. agric. Res. 9: 73-95.

Gliemeroth, G., 1955. Wirkung der Düngerverteilung auf die Wurzelausbildung. In: De plantenwortel in de landbouw. Staatsdrukkerij, 's-Gravenhage, pp. 69-78.

Goedewaagen, M. A. J., 1955. De oecologie van het wortelstelsel der gewassen. In: De plantenwortel in de landbouw. Staatsdrukkerij, 's-Gravenhage, pp. 31-68.

Grobbelaar, W., 1963. Responses of young maize plants to root temperatures. Meded. Landbouwhogesch. Wageningen: 63-1.

Huck, M. G. \& D. Hillel, 1983. A model of root growth and water uptake accounting for photosynthesis, respiration, transpiration, and soil hydraulics. $A d v$. in Irrigation 2: 273-333.

Humphries, E. C., 1958. Effect of removal of a part of the root system on the subsequent growth of the root and the shoot. Ann. Bot. 22: 251-257.

Ingestadt, T., 1974. Towards optimum fertilization. Ambio 3: 49-54.

Ingestadt, T., 1977. Nitrogen and plant growth. Maximum efficiency of nitrogen fertilizers. Ambio 6: 146-151.

Ingestadt, T., 1979a. Nitrogen stress in birch seedlings. I. Physiologia Plantarum 45: 137-148.

Ingestadt, T., 1979b. Nitrogen stress in birch seedlings. II. Physiologia Plantarum 45: 149-157.

Ingestadt, T., 1979c. A definition of optimum nutrient requirements in birch seedlings. Physiologia Plantarum 46: 31-35.

Neth. J. agric. Sci. 31 (1983) 


\section{R. BROUWER}

Jager, A. de, 1979. Localized stimulation of root growth and phosphate uptake in Zea mays L. resulting from restricted phosphate supply. In: J. L. Harley \& R. Scott Russell (Eds.). The soil-root interface. Academic Press, London, pp. 391-403.

Jager, A. de, 1982. Effects of localized supply of $\mathrm{H}_{2} \mathrm{PO}_{4}, \mathrm{NO}_{3}, \mathrm{SO}_{4}, \mathrm{Ca}$ and $\mathrm{K}$ on the production and distribution of dry matter in young maize plants. Neth. J. agric. Sci. 30: 193-203.

Jager, A. de \& M. Posno, 1980. A comparison of the reaction to a localized supply of phosphate in Plantago major L., P. lanceolata L. and P. media L. Acta Bot. neerl. 28: 479-489.

Jones, M. M. \& N. C. Turner, 1978. Osmotic adjustment in leaves of sorghum in response to water deficits. Plant Physiol. 61: 122-126.

Kemp, D. R., 1981. The growth rate of wheat leaves in relation to the extension zone sugar concentration manipulated by shading. J. exp. Bot. 32: 141-150.

Kleinendorst, A. \& R. Brouwer, 1970. The effect of temperature of the root medium and of the growing point of the shoot on growth, water content and sugar content of maize leaves. Neth. J. agric. Sci. 18: $140-148$.

Kny, L., 1894. On correlation in the growth of roots and shoot. Ann. Bot. 8 (31) 265-280.

Kulayeva, O., 1962. Effects of roots on the metabolism of leaves in connection with the action of kinetin on leaves. I. Fiziologia Rast. (Plant Physiol., Wash.) 9: 229-231.

Lambers, J. Th., 1979. energy metabolism in higher plants in different environments. Thesis, State University Groningen (Netherlands), pp. 1-179.

Leopold, A. C., 1961. Senescence in plant development. Science 134: 1727-1732.

Loomis, W. E., 1953. Growth and differentiation in plants. Iowa State College Press, Ames, Iowa.

Louwerse, W., 1967. The influence of the plant nutrition status on bleeding and salt uptake. Acta Bot. neerl. 16: 42-55.

Noordwijk, M. van, 1983. Personal communication.

Novoa, R. \& R. S. Loomis, 1981. Nitrogen and plant production. Plant and Soil 58: 177-204.

Michael, G., 1980. The role of hormones in yield formation. In: Physiological aspects of crop productivity. International Potash Institute, pp. 85-116.

Reynolds, J. F. \& J. H. M. Thornley, 1982. A shoot-root partitioning model. Ann. bot. 49: 585-597.

Scott Russell, R., 1977. Plant root systems. Mc Graw - Hill, London.

Seligman, N. G., H. van Keulen \& J. Goudriaan, 1975. An elementary model of nitrogen uptake and redistribution by annual plant species. Oecologia (Berl.) 21: 243-261.

Sinclair, T. R. \& C. T. de Wit, 1975. Comparative analysis of photosynthate and nitrogen requirements in the production of seeds by various crops. Science 189: 565-567.

Sinclair, T. R. \& C. T. de Wit, 1976. Analysis of the carbon and nitrogen limitations in soybean yield. Agron. J. 68: 319-324.

Spek, L. Y., 1980. Influence of nitrate and aeration on growth and chemical composition of Zea mays L. In: R. Brouwer et al. (Eds), Structure and function of plant roots. Martinus Nijhoff, The Hague, pp. 395-398.

Spek, L. Y., 1983. Unpublished results.

Thornley, J. H. M., 1977. Root-shoot interactions. Symp. Soc. exp. Biol. 31: 367-389.

Troughton, A., 1977. Relationships between the root and shoot systems of grasses. In: J. K. Marshall (Ed.), The belowground exosystem. Science Series. no. 26, Colorado State University, pp. 39-51.

Trought, M. C. T. \& M. C. Drew, (1980). The development of waterlogging damage in wheat seedlings. Plant and Soil 54: 77-94.

Wagner, H. \& Michael, G., 1971. Der Einfluss unterschiedlicher Stickstoffversorgung auf die Cytokininbildung in Wurzeln. Biochem. Physiol. Pflanzen 162: 147-158.

Wareing, P. F., 1979. Growth substances and integration in the whole plant. Symp. Soc. exp. Biol. 31: 367-389.

Wit, C. T. de, R. Brouwer \& F. W. T. Penning de Vries, 1970. The simulation of photosynthetic systems. In: Prediction and measurement of photosynthetic productivity. Proceedings IBP/PP Technical Meeting, Trebon, 1969. Pudoc, Wageningen, pp. 47-70. 